\title{
Column - De onnozele belastingbetaler
}

Wie wil graag als onnozele belastingbetaler door het leven gaan? De associaties die de kwalificatie 'onnozel' oproept met wereldureemd gedrag dat voortvloeit uit een wat dom-brave levensinstelling zijn zodanig sterk dat zij oorspronkelijke betekenis van dit woord hebben verdrongen. Daarom zal de doorsnee belastingbetaler niet voor onnozel willen worden versleten, alhoewel daarmee naar de oorspronkelijke betekenis van het woord wordt gedoeld op fiscale deugdzaamheid, gedrag zonder boze bedoelingen in de geest van de wetgever. Als de trouwhartige belastingbetaler echter stelselmatig het etiket 'dom en onnozel' krijgt opgeplakt, wordt zijn rechtvaardigheidsnotie uitgehold en zijn bereidheid om hoge belastingen te betalen onder grote druk gezet.

Om die reden heb ik dan ook indertijd de titelkeuze 'Betalen is voor de dommen' van Flip de Kam voor zijn in 1977 uitgegeven boek dat met verve de miljardenmazen in onze belastingwet beschrijft, betreurd. Daarmee werd - wellicht onbedoeld - de belastingheffing geprofileerd als een louter rechtspositivistische aangelegenheid die geen ruimte laat voor ethische motivatie. Degene die bereid was de hoge progressieve tarieven van de loon- en inkomstenbelasting te betalen, terwijl een arsenaal van belastingconstructies binnen handbereik lag, betaalde simpelweg de tol van zijn precieze en benauwde levenshouding. Degene die zich evenwel wenste te bekennen tot de rekkelijken wist door profijtelijk gebruik van de belastingbesparende constructies, die als warme broodjes over de toonbank gingen, het fiscale leven aangenaam te houden. De suggestieve titel 'Betalen is voor de dommen' riep het gevoel op van 'iedereen doet het' en degene die het niet doet is een dief van zijn eigen portemonnaie.

De uitdagende titel had in 1977 ongetwijfeld een shocktherapeutische bedoeling, een speldeprik voor de fiscale wetgever. Op die wijze heeft De Kam zeker mede een aanzet gegeven tot reparatiewetgeving. Ook is zijn boek als constructie-etalage ongetwiffeld van invloed geweest op de kentering in de fiscale jurisprudentie, waarin het accent verschoof van de letter naar de geest van de wet. De bewustwording dat de inkomstenbelasting werd geheven op basis van een manipuleerbaar en volstrekt ondeugdelijk inkomensbegrip is mede de verdienste geweest van De Kam's journalistiek appetijtelijk gepresenteerde produkt.

Op 20 oktober 1988 is Flip de Kam gepromoveerd tot doctor in de rechtsgeleerdheid op zijn proefschrift 'Tax reform in a welfare state'. In de bij het proefschrift 
behorende stellingen grijpt hij terug op zijn publikatie uit 1977. Hij betrekt daarin als stelling: 'Betalen blijft voor de dommen'. Deze stelling wordt in het proefschrift niet als zodanig onderbouwd. In de context van de andere stellingen 'Nederland: belastingparadijs' en 'De belastingtarieven kunnen en moeten omlaag' wordt de bedoeling duidelijk.

Onze huidige hoge toptarieven en steile progressielijn zijn vermijdbaar en kennelijk slechts voor de domme belastingbetaler effectief.

Met de wenselijkheid van verlaging van de toptarieven kan ik het eens zijn. Maar de opnieuw gelegde relatie tussen belasting betalen en stupiditeit is zodanig ongenuanceerd dat een dergelijke stelling, - ondanks de ongetwijfeld goede bedoelingen die met zo'n prikkelende stelling worden beoogd - zeker in een wetenschappelijk geschrift, misplaatst is. Het daarin tot uitdrukking gebrachte cynisme dat belasting betalen slechts een kwestie van domheid is, is grievend voor de burger die getrouw belasting betaalt, niet uit stupiditeit, maar vanwege het besef dat gebruikmaking van allerlei gekunstelde belastingconstructies onmaatschappelijk, miezerig gedrag impliceert waaraan men zich niet behoort over te geven. De stelling suggereert ten onrechte dat het normaal is dat elke burger zijn belastingverplichtingen minimaliseert. Alsof de homo economicus niet uitgerust is met enig ethisch besef. Voorts gaat de stelling eraan voorbij dat er een grote categorie belastingbetalers is die conform de progressieve tarieven betalen, gewoon omdat hun inkomen geheel en al aan de bron met loonbelasting wordt belast of omdat hun maatschappelijke positie vordert dat zij zich onthouden van anti-fiscaal gedrag. Of zijn ook dit de onnozelen van onze maatschappij?

Als De Kam met zijn stelling bedoelt te betogen dater nog steeds een onaanvaardbaar grote discrepantie is tussen de rechtvaardigheidsnotie, inhoudende dat belasting naar draagkracht moet worden betaald, en de fiscale praktijk, dan wil ik dat gaarne onderschrijuen. Het gelijkheidsbeginsel vordert dat met alle kracht gestreefd wordt naar een deugdelijker inkomensbegrip. Voor fiscalisten is de gebrekkigheid daarvan evident. Weldoordachte, evenwichtige wetgeving is daartoe vereist. Het beroep op de geest van de wet om eventuele rechtstekorten op te heffen is daarvoor immers een ontoereikend correctief. Voorts impliceert dit dat de bedoelingen van de wetgever bekend zijn. Dit is echter lang niet altijd het geval. Men mag weliswaar van de wetgever verwachten dat hij zo zorguuldig mogelijk zijn bedoelingen kenbaar maakt, zodat men daarnaar in het concrete geval niet behoeft te gissen, maar in de praktijk heeft het door tijdsdruk aan die zorguuldigheid al te vaak ontbroken.

Dit alles schaadt het respect voor de wet in hoge mate. Het werkt rechtsonzekerheid en politisering van de uitvoering van de wet in de hand en holt de legitimatie van het beroep op de geest van de wet, en daarmee ook de belastingmoraal, uit. Maar dit alles heeft bepaald niets met domheid van de belastingbetaler te maken. Ook heeft de wetgever niet geheel stil gezeten. Hij heeft omvangrijke reparatiewetgeving tot stand gebracht. Weliswaar blijft er nog veel te wensen over, maar dit geeft onvoldoende basis voor De Kam's ongenuanceerde stelling, behorend bijeen overigens boeiend proefschrift, dat betalen nog steeds voor de dommen is. 